\title{
Gene and genetic diagnostic method patent claims: a comparison under current European and US patent law
}

\author{
Isabelle Huys ${ }^{1,2}$, Geertrui Van Overwalle ${ }^{2,3}$ and Gert Matthijs ${ }^{\star 4}$
}

The paper focuses on the fundamental debate that is going on in Europe and the United States about whether genes and genetic diagnostic methods are to be regarded as inventions or subject matter eligible for patent protection, or whether they are discoveries or principles of nature and thus excluded from patentability. The study further explores some possible scenarios of American influences on European patent applications with respect to genetic diagnostic methods. Our analysis points out that patent eligibility for genes and genetic diagnostic methods, as discussed in the United States in the Association of Molecular Pathology versus US Patent and Trademark Office decision, is based on a different reasoning compared with the European Patent Convention.

European Journal of Human Genetics (2011) 19, 1104-1107; doi:10.1038/ejhg.2011.76; published online 8 June 2011

Keywords: genetic diagnostic testing; patents; breast cancer; genetic services; Fragile X syndrome; Factor V Leiden

\section{INTRODUCTION}

The recent ruling by Judge Robert Sweet from the US Court for the Southern District of New York in a case between the Association of Molecular Pathology (AMP) and the US Patent and Trademark Office (USPTO) invalidated seven patents claiming genes and genetic diagnostic methods held by Myriad Genetics. ${ }^{1}$ This decision opened another episode in the saga on breast cancer (BRCA) genes that has stirred the patent and genetic community during the past decade. The case has received much attention and has been commented upon broadly and vigorously. ${ }^{2}$ In Europe, similar claims to the $B R C A$ genes and genetic diagnostic methods have survived during the opposition and appeal proceedings at the European Patent Office (EPO), ,3 albeit with narrower scope. It is remarkable how only a few patents and the worldwide reaction they provoke have restarted the discussion about the patentability of genes (eg, DNA sequences per se) and of processes in which genes are being used (eg, genetic diagnostic methods). The AMP versus USPTO decision has reopened the fundamental debate about whether genes and genetic diagnostic methods are to be regarded as inventions or subject matter eligible for patent protection, or whether they are discoveries or principles of nature, and thus excluded from patentability. Recent studies on US developments regarding the patenting of genes and/or genetic diagnostic methods ${ }^{5,6}$ have focused on the controversies surrounding the patentability criteria, notably the novelty and non-obviousness aspects. The present paper aims at revisiting the very nature of genes and genetic diagnostic methods as subject matter for patents in a comparative way. We will briefly examine whether and, if so, why genes and genetic diagnostic methods can be qualified as inventions or statutory subject matter under the current European and US legislation and case law and, in doing so, we will compare European with US courts' reasonings on this point. We also intend to sketch a few scenarios of the influence of US case law on European patent applications with respect to genetic diagnostic methods.
Our analysis shows that the pendulum - the analogy was used by Kesselheim et $a l^{2}$ in their recent contribution in New Eng J Med - has swung further in the United States than it has in Europe. The reason for this might be that so far in Europe the BRCA gene and related method claims have only been attacked in opposition and appeal procedures within the EPO, and have not yet been reviewed by the national courts of EPO Member States.

\section{DIVERGING VIEWS ON ‘ISOLATED’ GENES AND GENETIC DIAGNOSTIC METHODS}

Patentability requirements in general

In Europe, the general requirements as to when European patents shall be granted are laid down in Article 52(1) of the European Patent Convention (EPC). Patents shall be awarded for any inventions, which are susceptible of industrial application, which are new and which involve an inventive step. The EPC does not explicitly define the concept of invention as such, although certain courts and legislators in EPC contracting states have reflected on this issue..$^{7-9}$ On the other hand, the implementing regulations to the EPC do specify that the invention must have technical features (Rule 43(1)), which is related to a technical field (Rule 42(1)(a)) and concerned with a technical problem (Rule $42(1)(c))$. It is clear from these rules that 'technicality' is a key precondition for qualification as a patentable invention in Europe.

Articles 52(2) and 52(3) of EPC list exclusions, which should not be regarded as inventions, if claimed 'as such', because they are abstract in nature (discoveries) or non-technical in nature (scientific theories or methods for performing mental acts).

In US patent law, general requirements for patentability are listed in 35 USC §101. This article defines that subject matter may be patentable, provided it or its improvement belongs to one of four distinct classes, namely, a process, machine, manufacture or composition of matter. It has to be new, useful and non-obvious (35 USC \$103).

\footnotetext{
${ }^{1}$ Research Centre for Pharmaceutical Care and Pharmaco-Economics, Department of Pharmaceutical Sciences, University of Leuven, Leuven, Belgium; ${ }^{2}$ Centre for Intellectual Property Rights, Faculty of Law, University of Leuven, Leuven, Belgium; ${ }^{3}$ Tilburg Institute for Law, Technology and Society, Faculty of Law, Tilburg University, The Netherlands; ${ }^{4}$ Centre for Human Genetics, University of Leuven, Leuven, Belgium

*Correspondence: Professor G Matthijs, Centre for Human Genetics, University of Leuven, Herestraat 49, Leuven 3000 , Belgium. Tel: +32 1634 6070

Fax: +32 1634 6060; E-mail: Gert.Matthijs@uzleuven.be

Received 15 September 2010; revised 4 March 2011; accepted 30 March 2011; published online 8 June 2011
} 
A precondition for patentability as to its 'technical character' does not seem to be explicitly present in US patent law. Although the United States does not have a statutory counterpart to Article 52(2) EPC, exceptions to patentability are established by case law, and certain categories are also excluded from patentability, such as products of nature, laws of nature and/or natural phenomena, abstract ideas or basic human knowledge or thought. ${ }^{10}$

With respect to method claims, the US Court of Appeals of the Federal Circuit (CAFC) investigated in In re Bilski ${ }^{6,11}$ whether or not a process claim is a principle of nature. The court in Bilski developed the 'machine-or-transformation test' to be applied to process claims. With regard to this test, the court ruled that a process is patentable under 35 USC $\S 101$ if 'it is tied to a particular machine or apparatus' or 'it transforms a particular article into a different state or thing. This use of a specific machine or the transformation of a particular product (eg, a protein) must be central to the purpose of the method. ${ }^{6,11}$ The test triggers several questions, for instance, what form or amount of transformation suffices. In the meantime, the Bilski case was handled before the Supreme Court in the Bilski versus Kappos ${ }^{12}$ decision. The Supreme Court concluded that the machine-or-transformation test is not the sole exclusive test for patent eligibility. Although Bilski related to business methods, the test has been applied in several biotechnology cases. In Prometheus Laboratories Inc. v. Mayo Collaborative Services, ${ }^{13}$ for instance, a claim to a method of optimizing therapeutic efficacy by first administering a particular drug to a patient and then using the patient's metabolite level to adjust future drug doses was regarded as patentable. The claimed steps were essentially 'method of treatment' steps, which, according to the CAFC, are always transformative in nature.

\section{Claims on genes}

Both European and US patent law stress that a gene has to be isolated to be patentable. However, especially since the ruling of Judge Sweet, views on this requirement differ between both continents.

In Europe, an isolated gene, that is, 'an element isolated from the human body or otherwise produced by means of a technical process', may constitute a patentable invention, 'even if the structure of that element is identical to that of a natural element' (Rule 29(2)). ${ }^{14}$ Furthermore, 'the industrial application of a sequence or a partial sequence of a gene must be disclosed in the patent application' (Rule 29(3)). European geneticists have called the wording of Rule 29(2) 'a semantic game, ${ }^{15}$ as it simply refers to anyone's interpretation of words.

In the United States, the landmark is the Diamond versus Chakrabarty case: already in 1980, the Supreme Court held that a humanmade, living, genetically engineered bacterium, capable of breaking down components of crude oil, was patentable under 35 USC $\$ 101 . .^{10}$ In its reasoning, the Court considered that the claim was to a 'nonnaturally occurring manufacture or composition of matter - a product of human ingenuity having a distinct name, character and use.' ${ }^{10}$ Therefore, the product had to have 'markedly different characteristics' from a product of nature. ${ }^{10}$ After the Chakrabarty decision, genes were regarded as patentable, for the act of 'isolation' or 'purification' was perceived at giving a human-made character to human genes, distinguishing them from naturally occurring genes.

The Chakrabarty ruling was cited as a 'lawyers trick' in the 'AMP versus USPTO' decision of Judge Sweet of the US Court for the Southern District of New York. ${ }^{1}$ He ruled that isolated DNA is not markedly different, as it exists in nature and therefore is considered unpatentable under 35 USC $\$ 101$. 'Mere purification of a DNA does not alter its essential characteristics - its nucleotide sequence - that is defined by nature and central to both its biological function within the cell and its utility as a research tool in the lab' (page 136 in the AMP versus USPTO ruling $^{1}$ ). Hence, purification or isolation does not transform DNA into patentable subject matter. According to Judge Sweet, 'the requirement that the DNA used to be isolated is ultimately a technological limitation to the use of DNA in its fashion, and a time may come when the use of DNA for molecular or diagnostic purposes may not require such purification' (page 132 in the AMP versus USPTO ruling $^{1}$ ). This will be the case when the entire genome will be read at the single-molecule level. Judge Sweet considered DNA to be the physical embodiment of laws of nature and of information that defines the construction of the human body. That is why the structural and functional differences between native and isolated genes do not render DNA 'markedly different'.

According to Judge Sweet, 'the identification of the BRCA genes is unquestionably a valuable scientific achievement for which Myriad deserves recognition, but that is not the same as concluding that it is something for which they are entitled for a patent'. The techniques of purification and isolation of DNA are 'well-known to those skilled in the art' and, as a consequence, such claims on isolated DNA constitute unpatentable subject matter under 35 USC $\$ 101$. This is also very much the opinion of geneticists, both in Europe ${ }^{15}$ and in the United States. ${ }^{16}$ Recently, the US Department of Justice (DoJ) filed an amicus curiae brief in the AMP versus USPTO case, confirming that unmodified human genes should not be patentable because they are products of nature, and the mere isolation of a gene without further alteration or manipulation does not change its nature. ${ }^{17}$ However, the DoJ reasoned different from the District Court in arguing that manipulated genetic material, such as complementary DNA, vectors or recombinant plasmids, should be regarded as patentable. ${ }^{17}$

Comparing US with European views shows that Judge Sweet appears to deny exactly what has been enacted to be patentable in Europe. Statutory, the Biotechnology Directive 98/44/EC makes clear that an invention based on 'an element isolated from the human body or otherwise produced by means of a technical process, which is susceptible of industrial application, is not excluded from patentability, 'even if the structure of that element is identical to that of a natural element' (Rule 29(2) and Recital 20). ${ }^{14}$ The possible reason why isolated genes are not excluded from patentability is that the legislator takes the view that an isolated gene contains technical information, in the sense that the aspect of 'isolation' is considered to be the result of 'technical processes used to identify, purify and classify it, techniques which human beings alone are capable of putting into practice and which nature is incapable of accomplishing by itself' (Recital 21). ${ }^{14}$

\section{Claims on genetic diagnostic methods}

With regard to genetic diagnostic methods, patents are granted both in Europe and the United States, although views on the nature of genetic diagnostic methods differ.

In Europe, Article 53(c) EPC states that patents shall not be granted in respect of diagnostic methods practised on the human body. Conversely, diagnostic methods per se, not directly carried out on the human body, are patentable. This seemingly simple regime has to be considered carefully. In decision G1/04 ${ }^{18}$ of the Enlarged Board of Appeal of the EPO, the Board has defined diagnostic methods practised on the human body as methods comprising the following consecutive steps: (1) the examination phase involving the collection of data, (2) the comparison of these data with standard values, (3) the finding of any significant deviation, that is, a symptom, during the comparison and (4) the attribution of the deviation to a particular clinical picture, that is, the deductive medical or veterinary decision phase. 
Several further findings of the Enlarged Board of the EPO in G1/04 are highly relevant. ${ }^{18}$ First, the Board clarifies 'diagnosis' in connection with the exemption of diagnostic methods practised on the human body as 'the determination of the nature of a medicinal condition intended to identify a pathology' (reasons for the opinion, point 5.1 in G1/04. ${ }^{18}$ In order to be excluded from patentability, the diagnostic method has to include all the steps mentioned earlier (1-4). Second, the Board explains that the criterion 'practised on the human body' is to be considered only in respect of technical method steps. The deductive decision phase in itself is a non-technical, purely intellectual exercise, but patents claiming only a deductive decision phase are excluded from patentability pursuant to Article 52(2) EPC because they encompass only a mental act (reasons for the opinion, point 6 in G1/04. ${ }^{18}$ Such methods must necessarily further include preceding technical steps not practised on the human body, in order to be patentable. Third, the Board also shed some light on diagnostic methods when some or all steps are carried out by in vitro techniques in a laboratory, hence not directly on the human body, for example, genetic diagnostic methods (such as DNA sequencing or the use of microarrays). Such method steps are of a purely technical nature; thus, genetic diagnostic methods claiming these technical steps are in principle not excluded from patentability under European law. The method steps of 'obtaining results or findings' do not constitute a sufficient basis for denying patentability by virtue of Article 53(c) EPC (reasons for the opinion, point 6.2.3, G1/04). ${ }^{18}$ The same reasoning was applied in November 2008 in the EPO decisions on the BRCA1 patents (in the cases T80/05, T666/08 and T1213/05) related to claims for diagnosing a predisposition for breast and ovarian cancer in a human subject.

In the United States, the exact nature of genetic diagnostic method claims was also explored in AMP versus USPTO, whereby the US Court of the Southern District of New York for the first time applied the machine-or-transformation test ${ }^{11}$ to genetic diagnostic method claims. ${ }^{1}$ The court looked at whether the method claims were tailored narrowly enough to encompass only a particular application of a fundamental principle (the latter not being patentable), rather than preempting the principle itself and being a method with a transformative character (the latter being patentable). According to Judge Sweet, DNA sequencing is in fact 'a process by which one reads or determines the ordering of the nucleotides within a DNA molecule' (page 33 in the AMP versus USPTO ruling ${ }^{1}$ ), 'to illuminate the 'information nature' dictated in that person's genome' (definition from the AMP versus USPTO ruling). Some of the method claims at stake in AMP versus USPTO (eg, claim 1 of US patent 5709 999) focus on the process of analyzing a BRCA1 sequence and on examining whether or not the specified naturally occurring mutation exists. Other claims (eg, claim 1 of US patent 5710001) are directed to comparing two gene sequences to establish if any differences exist and do not specify any limitations on the method of comparison. In AMP versus USPTO, the Court found that analyzing and comparing, as established in the method claims, are directed only to the abstract mental processes of comparing and analyzing gene sequences, and are therefore not transformative and not patentable. The Court also considered that so-called transformations associated with isolating and sequencing are also data-gathering steps that are not central to the detection process, as required for the Bilski test. Judge Sweet argued that the situation is reminiscent of a claim considered in In re Grams, ${ }^{19}$ where the patent contained a claim to a method of diagnosing an abnormal condition in an individual, consisting of two steps that are as follows (1) performance of clinical laboratory tests to obtain data for the parameters and (2) analyzing which data ascertain the existence and identity of an abnormality. The Court in
Grams concluded that the objective of performing laboratory tests was to gather clinical data and that the core of the invention was the mathematical algorithm, which is considered unpatentable. As a result of the legal analysis in AMP versus USPTO, the genetic diagnostic method claims were invalidated. ${ }^{1}$

Comparing European with US views on patenting genetic diagnostic methods, the AMP versus USPTO decision obviously articulates an opinion that is different from the one in G1/04 and the European BRCA case. The US District Court found that analyzing and comparing DNA sequences are not patentable methods, whereas this issue has not been addressed in depth in Europe in the G1/04 or BRCA cases. However, steps of data gathering were considered patentable in Europe.

\section{APPLYING US PATENT STANDARDS TO EUROPEAN PATENT CLAIMS}

In a recent ruling by the Court of Justice of the European Union relating to genetically modified plants and seeds (Monsanto versus Cefetra), ${ }^{20}$ the Court questioned the scope of protection conferred to genes. However, no principled analysis of the patentability of genes took place. Hence, in Europe, the patentability of genes still follows the statutory principle laid down in the EPC (Rule 29). But for how long? Will the AMP versus USPTO verdict affect the situation in Europe? With respect to genetic diagnostic methods, will the CAFC's machine-or-transformation rule reach the European continent?

It is highly unlikely that those decisions will have such a far-reaching effect. However, history has shown that groundbreaking US Supreme Court decisions can influence patent law and practice all over the world. An example of this is the Chakrabarty decision, where it has been suggested that in the years following this case, the TRIPS Agreement (1994) sought ways to regularize and internationalize the technological and legal culture that flowed in that decision. ${ }^{21}$ In June 2010, the US Supreme Court reached a final conclusion on the CAFC's machine-or-transformation test in Bilski versus Kappos. ${ }^{12}$ The Supreme Court ruled that the machine-or-transformation test is a valuable clue to the question of process patent eligibility, but it held that this is not an exclusive test for process or method patents. The Court encouraged the CAFC to develop additional final criteria that would help define the kind of process claims that are patentable. ${ }^{12}$

Although it is highly unlikely that the machine-or-transformation test as interpreted by the Supreme Court will be applied in the appeal on AMP versus USPTO, it remains interesting to ask whether the machine-or-transformation test could ever become part of European patent law and practice. If so, then hundreds of genetic diagnostic method patents might be invalidated.

In Huys et $a l^{22}$ we listed several method claims in European patents, which included (explicitly or implicitly) steps such as the isolation or sequencing of human DNA. These steps would lack any form of transformative character as defined in the Supreme Court decision Bilski versus Kappos. ${ }^{12}$ For instance, the in vitro detection procedure of the Fragile X syndrome claimed in EP580621 (claim 14) (see Supplementary Information) comprises the steps of a treatment of a sample of genomic DNA, separating the fragments and visualizing and comparing the results obtained with control fragments (eg, by performing Southern blot or fragment analysis). Measuring and comparing gene fragments does not cause an alternation of the gene at hand. Taking the claim in its entirety, the essence of the claim is the act of comparing genes in normal and affected persons. Therefore, the claimed process is, in fact, a basic scientific principle, namely, that an alteration between the gene FMR-1 in normal and affected individuals 
indicates a mutation for Fragile X syndrome. Hence, a real transformation is arguably not present.

Other examples include claim 1 of EP885309 (Friedreich ataxia; see Supplementary Information) claiming a method of screening individuals for a mutation that leads to Friedreich ataxia, or claim 1 of EP0569527 (familial adenomatous polyposis; see Supplementary Information), which relates to 'a method of diagnosing or prognosing a neoplastic tissue of a human', comprising only a step of detecting (read: sequencing) an alteration within a gene sequence. Illustrative is also claim 1 of EP696325 (Factor V Leiden; see Supplementary Information) on a method for screening for the presence of a genetic defect associated with thrombosis and/or a poor anticoagulant response to activated protein $\mathrm{C}$, the said method comprising determination of the presence of a mutation in the nucleic acid. When applying the machine-or-transformation test, these methods would constitute nothing more than 'data-gathering steps' that are not central to the purpose of the claimed process and hence would not qualify as transformations.

It remains also interesting to ask whether European standards from other technical fields could be applied to European genetic diagnostic method claims. Recently, the Enlarged Board of Appeal of the EPO formulated a new European standard for computer-implementing inventions, requiring a 'further technical effect' for such inventions to be patentable. ${ }^{23}$ However, for the same reason of unrelated technicality, it is very unlikely that this new European requirement will be applied in the field of genetic diagnostic testing.

Whatever way it goes, whether in Europe the machine-or-transformation test will be applied to genetic diagnostic tests or not, or whether new European standards from other technical fields will be applied to genetic diagnostic methods, another important unsettled issue relates to the clarity of claims and to the sufficiency of disclosure in the patent description. In this respect, Article 84 EPC can become quite relevant, as it requires that in order to be patentable, an independent claim must recite all the essential features necessary for a clear and complex definition of a particular invention. Obviously, such features are mostly of a technical nature. Recently, the national court of an EPC member state considered in Eli Lilly versus Human Genome the issue of 'sufficiency' in relation to DNA patents, invalidating a genetic diagnostic patent because it was held to be insufficiently disclosed. ${ }^{24}$

\section{CONCLUSION}

Diverging views across Europe and the United States on patenting genes and genetic diagnostic methods exist. With respect to genes, the ruling in the AMP versus USPTO decision, classifying an 'isolated' gene as a product of nature, clearly differs from the statutory text of the EPC, holding a gene patentable if isolated from its natural environment. With respect to methods, genetic diagnostic method claims did not survive the machine-or-transformation test in AMP versus USPTO and were regarded as laws of nature, hence unpatentable. In Europe, such methods are in principle not excluded from patentability.

Although it is very unlikely that the AMP versus USPTO decision will influence European patent law and practice, it is interesting to look at the possible outcome of the Supreme Court's machine-ortransformation test in Bilski versus Kappos when applied in Europe.

The recent developments in the United States and in Europe, and the resulting legal uncertainty in the field of genetic diagnostic testing might trigger the Trilateral Offices (USPTO, EPO and Japanese Patent Office) to take action. In view of the common objective to harmonize the protection of industrial property rights and to contribute to an 'increasingly efficient worldwide patent system in the 21 st century, ${ }^{25}$ we hope that the current situation will spur this forum to restore legal certainty with respect to patenting genes and genetic diagnostic methods.

\section{CONFLICT OF INTEREST}

The authors declare no conflict of interest.

\section{AUTHOR'S BACKGROUND}

IH is assistant professor of patent law at the Faculty of Pharmaceutical Sciences, University of Leuven (Belgium) and associated with the Centre for Intellectual Property Rights, Faculty of Law, University of Leuven (Belgium). She has a Masters in Intellectual Property Rights (LLM) from the Max-Planck-Institute for Intellectual Property Rights, Tax and Competition Law in Munich. GVO is professor of IP law at the Centre for Intellectual Property Rights, Faculty of Law, University of Leuven (Belgium) and professor of patent law and new technologies at the Tilburg Institute for Law, Technology and Society (the Netherlands). GM is professor of human genetics and head of the Laboratory for Molecular Diagnostics, Centre for Human Genetics, Faculty of Biomedical Sciences, University of Leuven (Belgium).

1 Association of Molecular Pathology v. U.S. Patent and Trademark Office: USDC SDNY 09 Civ. 4515, 29 March 2010.

2 Kesselheim AS, Mello MM: Gene patenting - is the pendulum swinging back? N Engl J Med 2010; 362: 1855-1858.

3 Matthijs G: The European opposition against the BRCA gene patents. Fam Cancer 2006; 5: 95-102.

4 Matthijs G, Halley D: European-wide opposition against the breast cancer gene patents. Eur J Hum Genet 2002; 10: 783-785.

5 Chandrasekharan S, Cook-Deegan R: Gene patents and personalized medicine - what lies ahead? Genome Med 2009; 1: 92.

6 Wu G: Patenting biotech beyond the central dogma. Nat Biotechnol 2010; 28 : 230-233.

7 Biogen Inc. v. Medeva Plc. Hepatitis-B-virus, 1997: R.P.C. 1 (41-42)

8 Red Dove (Rote Taube), X ZB 15/67: Federal Supreme Court, 1969. 1 I.I.C. 136, 1970

9 Explanatory Memorandum (Memorie van Toelichting): Parliamentary Documents (Parlementaire Stukken), Kamer, 50 K1886, Article 5, Belgium, 2001-2002.

10 Diamond v. Chakrabarty. 447 US 303 (1980).

11 In re Bilski. 545 F.3d at 961-2 (Fed. Cir. 2008).

12 Bilski v. Kappos. U.S., No. 08-964 (6/28/10).

13 Prometheus Laboratories, Inc. V. Mayo Collaborative Services: No. 2008-1403 (Fed. Cir. 2009).

14 Directive 98/44/EC of the European Parliament and of the Council of 6 July 1998 on the legal protection of biotechnological inventions: Official Journal L 213, 30/07/1998 P. 0013-0021. The Directive was incorporated in the EPC in 1999. The wording of Rule 29 (2) is identical to the wording of Article 5 (2) of the Directive.

15 Matthijs G, Ayme S (guest eds).: Patenting and licensing in genetic testing. Eur J Hum Genet 2008; 16(Suppl 1): S1-S50.

16 American College of Medical Genetics: Position Statement on Gene Patents and Accessibility of Gene Testing (1999), as reconfirmed in 2005 http://genetics.faseb. org/genetics/acmg/pol-34.htm

17 Appeal from the United States District Court for the Southern District of New York, in case no. 09-CV-4515: Senior Judge Robert W. Sweet. Brief for the United States as amicus curiae in support of neither party (No. 2010-1406).

18 G1/04, http://www.epo.org/law-practice/case-law-appeals/pdf/g040001ex1.pdf, 2005.

19 In re Grams. 888 F.2d at 837 (Fed. Circ. 1989).

20 Monsanto v. Cefetra: (ECJ C-428/08).

21 Rimmer M: Intellectual Property Rights and Biotechnology. Northhampton: Edward Elgar Publishing Limited, 2007.

22 Huys I, Berthels N, Matthijs G, Van Overwalle G: Legal uncertainty in the area of genetic diagnostic testing. Nat Biotechnol 2009; 27: 903-909.

23 G3/08, http://www.epo.org/law-practice/case-law-appeals/pdf/g080003ex1.pdf.

24 Eli Lilly v Human Genome: EWCA Civ 33, 2010.

25 Trilateral Offices Website http://www.trilateral.net/index.html;jsessionid=1 eoqe443 ybb8s. 